\title{
5th German Conference on Chemoinformatics: 23. CIC-Workshop. November 8-10, 2009, Goslar, Germany
}

\author{
Frank Oellien ${ }^{1 *}$, Uli Fechner ${ }^{2}$, Thomas Enge ${ }^{3}$ \\ From 5th German Conference on Cheminformatics: 23. CIC-Workshop \\ Goslar, Germany. 8-10 November 2009
}

From the $8^{\text {th }}$ to the $10^{\text {th }}$ November 2009 , the Chemistry-Information-Computers (CIC) division of the German Chemical Society (GDCh) has invited the chemoinformatics and modeling community to Goslar, Germany to participate in the 5th German Conference on Chemoinformatics (GCC 2009). The international symposium addressed a broad range of modern research topics in the field of computers and chemistry. The focus was on recent developments and trends in the fields of Chemoinformatics and Drug Discovery, Chemical Information, Patents and Databases, Molecular Modeling, Computational Material Science and Nanotechnology. In addition, other contributions from the field of Computational Chemistry were welcome.

The conference was opened traditionally with a "FreeSoftware-Session" on Sunday afternoon right before the official conference opening at $5 \mathrm{pm}$ including three talks about the Open Source projects Bingo, Dingo and OrChem. In parallel the "Chemoinformatics Market Place" took place including software tutorials by Chemical Computing Group, Hemlholtz-Center Munich and the Cambridge Crystallograhic Data Center.

The scientific program was opened by an evening talk giving an overview on the field of Systems Chemistry (Günter von Kiedrowski). In addition, the program included six plenary lectures (Eberhard Voit (USA), Knut Baumann (Germany), Thomas Kostka (Germany), Anthony J. Williams (USA), Kalr-Heinz Baringhaus (Germany), Christoph Sotriffer (Germany)], 17 general lectures as well as 54 poster presentations.

Besides the scientific program a special highlight of the conference were the FIZ-CHEMIE-Berlin 2009

\footnotetext{
* Correspondence: frank.oellien@sp.intervet.com

${ }^{1}$ GDCh-CIC Division Chair, Intervet Innovation GmbH, Zur Propstei,

55270 Schwabenheim, Germany
}

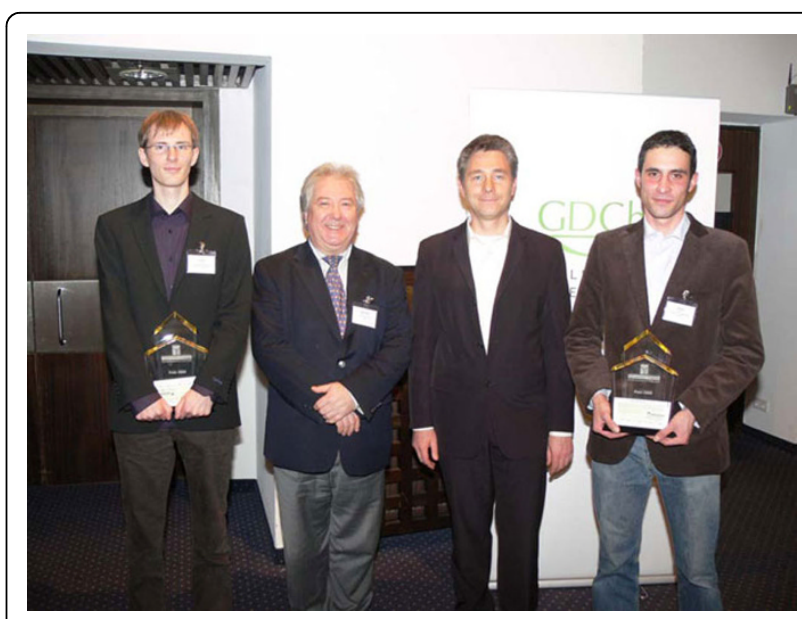

Figure 1 Fiz CHEMIE Berlin Awards 2009: from left to right, Frank Tristram (award for the best diploma thesis), Rene de Planque (Head of FIZ CHEMIE Verlin), Frank Oellien (Chair of the GDCh-CIC division), José Batista (award for the best PhD thesis).

awards on Monday afternoon (Figure 1). The CIC division awards this price each year to the best diploma thesis and the best $\mathrm{PhD}$ in the field of Computational Chemistry. The price for the $\mathrm{PhD}$ thesis was awarded to Dr. José Batista from the group of Prof. Dr. Jürgen Bajorath, University of Bonn for his dissertation "Analysis of Random Fragment Profiles for the Detaction of Structure-Activity Relationships". The award for the best diploma thesis has gone to Frank Tristram from the group of Dr. Wolfgang Wenzel, Karlsruher Institute of Technology with the title "Modellierubng der Hauptkettenbeweglichkeit in der rechnergestützten Medikamentenentwicklung". 


\section{Author details}

${ }^{1}$ GDCh-CIC Division Chair, Intervet Innovation GmbH, Zur Propstei,

55270 Schwabenheim, Germany. ${ }^{2} \mathrm{GDCh}-\mathrm{ClC}$ division board member, Beilstein-Institut zur Förderung der Chemischen Wissenschaften,

Trakehner Str. 7-9, 60487 Frankfurt, Germany. ${ }^{3}$ GDCh-CIC Division Co-Chair,

Fakultät für Chemie und Pharmazie, Universität München, Butenandtstr.

5-13, 81377 München, Germany.

Published: 4 May 2010

doi:10.1186/1758-2946-2-S1-A1

Cite this article as: Oellien et al: 5 th German Conference on

Chemoinformatics: 23. CIC-Workshop. November 8-10, 2009, Goslar,

Germany. Journal of Cheminformatics 2010 2(Suppl 1):A1.

\section{Publish with ChemistryCentral and every scientist can read your work free of charge}

"Open access provides opportunities to our colleagues in other parts of the globe, by allowing anyone to view the content free of charge."

$$
\text { W. Jeffery Hurst, The Hershey Company. }
$$

- available free of charge to the entire scientific community

- peer reviewed and published immediately upon acceptance

- cited in PubMed and archived on PubMed Central

- yours - you keep the copyright

Submit your manuscript here:

http://www.chemistrycentral.com/manuscript/<smiles>c1ccccc1</smiles>
Chemistry Central 